\title{
Biogeochemical properties of water in surface ponds on Antarctic fast ice and their relationship with underlying sea-ice properties
}

\author{
Daiki NOMURA, ${ }^{1 *}$ Daisuke SIMIZU, ${ }^{2}$ Hideo SHINAGAWA, ${ }^{3}$ Chinatsu OOUCHIDA, ${ }^{4}$ \\ Mitsuo FUKUCHI \\ ${ }^{1}$ National Institute of Polar Research, 10-3 Midori-cho, Tachikawa-shi, Tokyo 190-8501, Japan \\ E-mail: daiki.nomura@npolar.no \\ ${ }^{2}$ Institute of Low Temperature Science, Hokkaido University, Sapporo 060-0819, Japan \\ ${ }^{3}$ Shimoda Marine Research Center, University of Tsukuba, 5-10-1 Shimoda, Shizuoka 415-0025, Japan \\ ${ }^{4}$ Graduate School of Marine Science and Technology, Tokyo University of Marine Science and Technology, 4-5-7 Konan, \\ Minato-ku, Tokyo 108-8477, Japan \\ ${ }^{5}$ National Institute of Polar Research, 10-3 Midori-cho, Tachikawa-shi, Tokyo 190-8501, Japan
}

\begin{abstract}
Surface ponds on Antarctic fast ice were examined by measuring temperature, salinity and concentrations of chlorophyll a (Chl-a), dissolved inorganic carbon (DIC) and nutrients $\left(\mathrm{NO}_{3}+\mathrm{NO}_{2}\right.$, $\mathrm{PO}_{4}$ and $\mathrm{SiO}_{2}$ ) in the surface pond water and under-ice water. Sea-ice cores were also collected from the bottom of a surface pond (pond-ice core) and from a site away from the pond (bare-ice core). Timeseries measurements of surface pond water temperature showed that it varied with solar radiation rather than with air temperature. Comparison of water properties between surface pond water and under-ice water suggested that DIC and nutrients were consumed by biological productivity during pond formation. Depth profiles of nutrient concentrations in the pond-ice core suggested the remineralization of organic matter at the bottom of the surface pond. The Chl-a concentration was lower at the bottom of the pond-ice core than in the bare-ice core, suggesting that surface pond formation reduces ice algae abundance in sea ice because meltwater flushes algae from the porous sea ice into the under-ice water.
\end{abstract}

\section{INTRODUCTION}

Surface melting of sea ice is triggered by solar radiation during the spring and summer. Complete melting of snow over sea ice increases surface pond formation (Fetterer and Untersteiner, 1998). Additionally, surface ponds form by seawater inundation, particularly around pressure ridges (Ackley and Sullivan, 1994; Haas and others, 2001; Schnack-Schiel and others, 2001; Kennedy and others, 2002). The formation of a surface pond, a pool of water on the sea ice, dramatically affects the energy and mass balance (e.g. Ebert and Curry, 1993) and the optical properties of the underlying sea ice (e.g. Perovich and others, 2002). Surface pond formation can also alter the sea-ice structure and lead to under-ice meltwater pond formation (Eicken, 1994; Eicken and others, 2002). Moreover, surface pond formation affects the chemical and biological characteristics of the sea-ice-water system (Gradinger, 1996; Herborg and others, 2001; Schnack-Schiel and others, 2001; Kennedy and others, 2002).

In summer, up to $50 \%$ of the frozen surface of the Arctic Ocean is covered by surface ponds (Fetterer and Untersteiner, 1998), indicating the importance of understanding how surface ponds might relate to climate. The Surface Heat Budget of the Arctic Ocean (SHEBA) project, an interdisciplinary series of sea-ice field experiments focusing on mechanisms affecting the surface properties of Arctic sea ice, has contributed greatly to our knowledge of surface ponds (Perovich and others, 1999). Taylor and Feltham (2004) developed a model of surface pond formation on sea ice to clarify the sequential processes from sea-ice formation to its erosion in summer. Rösel and Kaleschke (2011) have

*Present address: Norwegian Polar Institute, Fram Centre, NO-9296 Tromsø, Norway. quantified changes in the area occupied by surface ponds throughout the seasonal cycle using satellite data on Arctic sea-ice coverage.

These studies of surface ponds, however, have focused mainly on ponds on Arctic sea ice, although surface pond formation on Antarctic sea ice is not uncommon (Ackley and Sullivan, 1994; Haas and others, 2001; Schnack-Schiel and others, 2001; Kennedy and others, 2002). Flooding of the snow/ice interface is a common feature of sea ice in Antarctica, where precipitation is high and sea ice is relatively thin. As a result, the snow cover usually does not melt completely and surface ponds do not form (Massom and others, 2001; Sturm and Massom, 2010). However, even in Antarctica, surface ponds on sea ice are found in areas of multi-year landfast ice near the continental coast (Wadhams, 2000) and around pressure ridges (Ackley and Sullivan, 1994; Haas and others, 2001; Kennedy and others, 2002). In addition, melting of wide areas $(\sim 10 \mathrm{~km})$ of multiyear fast ice and formation of surface ponds in LützowHolm Bay, East Antarctica, have been observed in satellite data (Enomoto and others, 2002). Although biogeochemical studies of surface ponds are important for understanding not only summertime ecology but also chemical cycles in atmosphere-ice-ocean systems, little information is available on the biogeochemistry of sea-ice surface ponds, particularly in Antarctica.

In this study, as a first step to understanding Antarctic surface ponds, we carried out a program of field measurements focusing primarily on the biogeochemical components of surface ponds. We also obtained a sea-ice core from the bottom of a surface pond and compared its physicochemical properties with those of an ice core collected away from the surface pond in order to clarify how surface pond formation affects the properties of the underlying sea ice. 

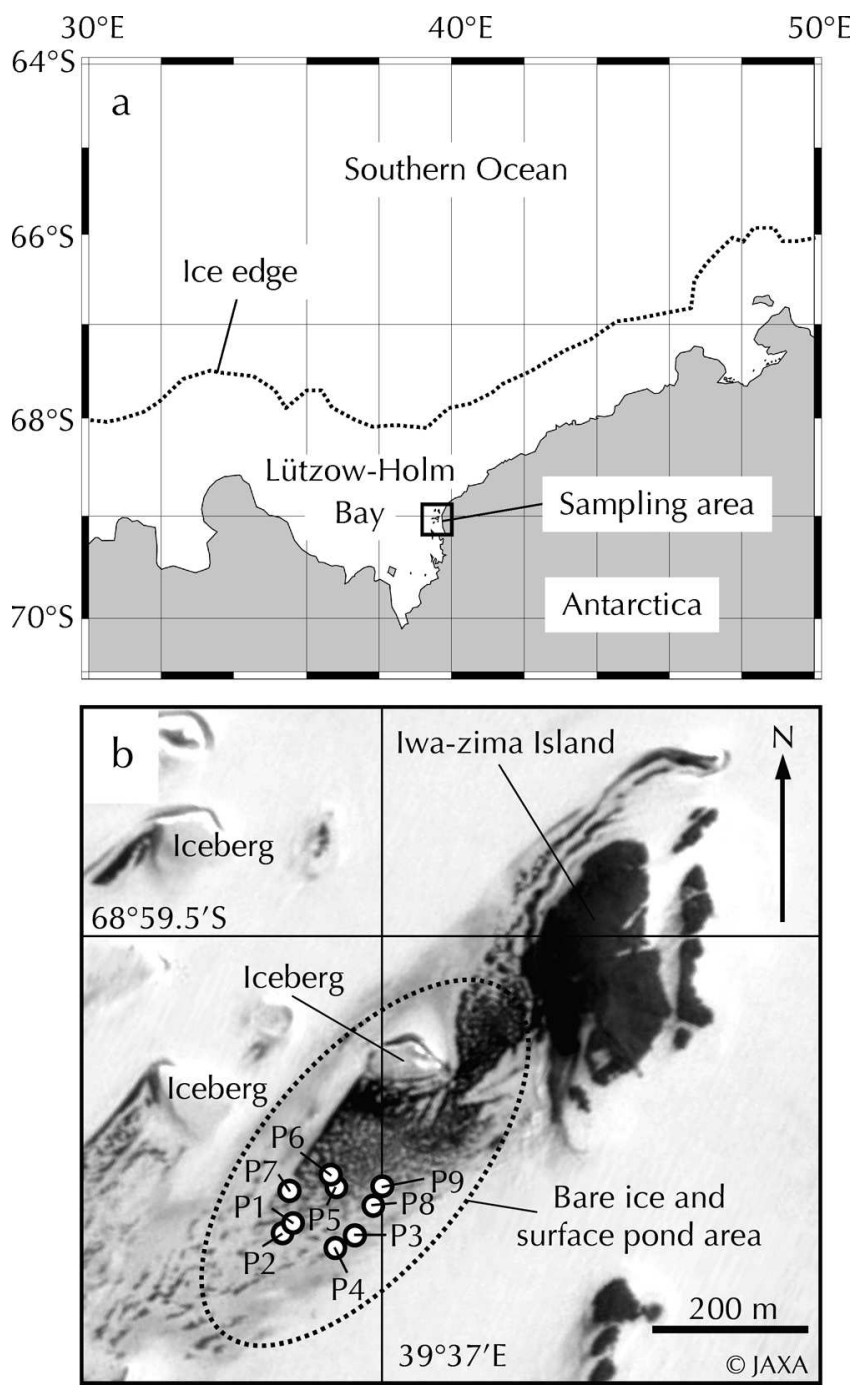

Fig. 1. (a) Location map of the sampling area in Lützow-Holm Bay, East Antarctica. The dotted line indicates the ice edge in February 2010. (b) The study region, showing the surface pond locations, near the coast of the Antarctic continent. This Advanced Land Observing Satellite (ALOS)/Panchromatic Remote-sensing Instrument for Stereo Mapping (PRISM) image was obtained on 26 January 2010.

\section{MATERIALS AND METHODS}

Surface pond water was collected from nine ponds on multiyear landfast ice in Lützow-Holm Bay from 29 January to 5 February 2010 (Fig. 1; Tables 1 and 2). During this period, snow accumulation was minimal on the downwind side of Iwa-zima Island and an iceberg, allowing the formation of a bare-ice region and surface ponds on the sea-ice surface (Fig. 1b). The water surface of all surface ponds was covered by thin ice (Table 1 ).

To sample the water in a surface pond, a $0.05 \mathrm{~m} \times 0.05 \mathrm{~m}$ hole was made in a thin ice surface with a hand-saw. Then surface pond water was pumped out through the hole with a diaphragm pump (EWP-01, As One Corporation, Osaka, Japan) from $0.3 \mathrm{~m}$ depth (Fig. 2a), and collected into a $12 \mathrm{~mL}$ glass screw-cap vial (Nichiden-Rika Glass Co. Ltd, Kobe, Japan) for measurement of salinity, a $500 \mathrm{~mL}$ Nalgene polycarbonate bottle (Thermo Fisher Scientific Inc., Waltham, MA, USA) for measurement of chlorophyll a (Chl a), a $120 \mathrm{~mL}$ amber glass vial (Maruemu Co. Ltd, Osaka, Japan) for measurement of the dissolved inorganic carbon (DIC) concentration, and a $10 \mathrm{~mL}$ polyethylene screw-cap vial
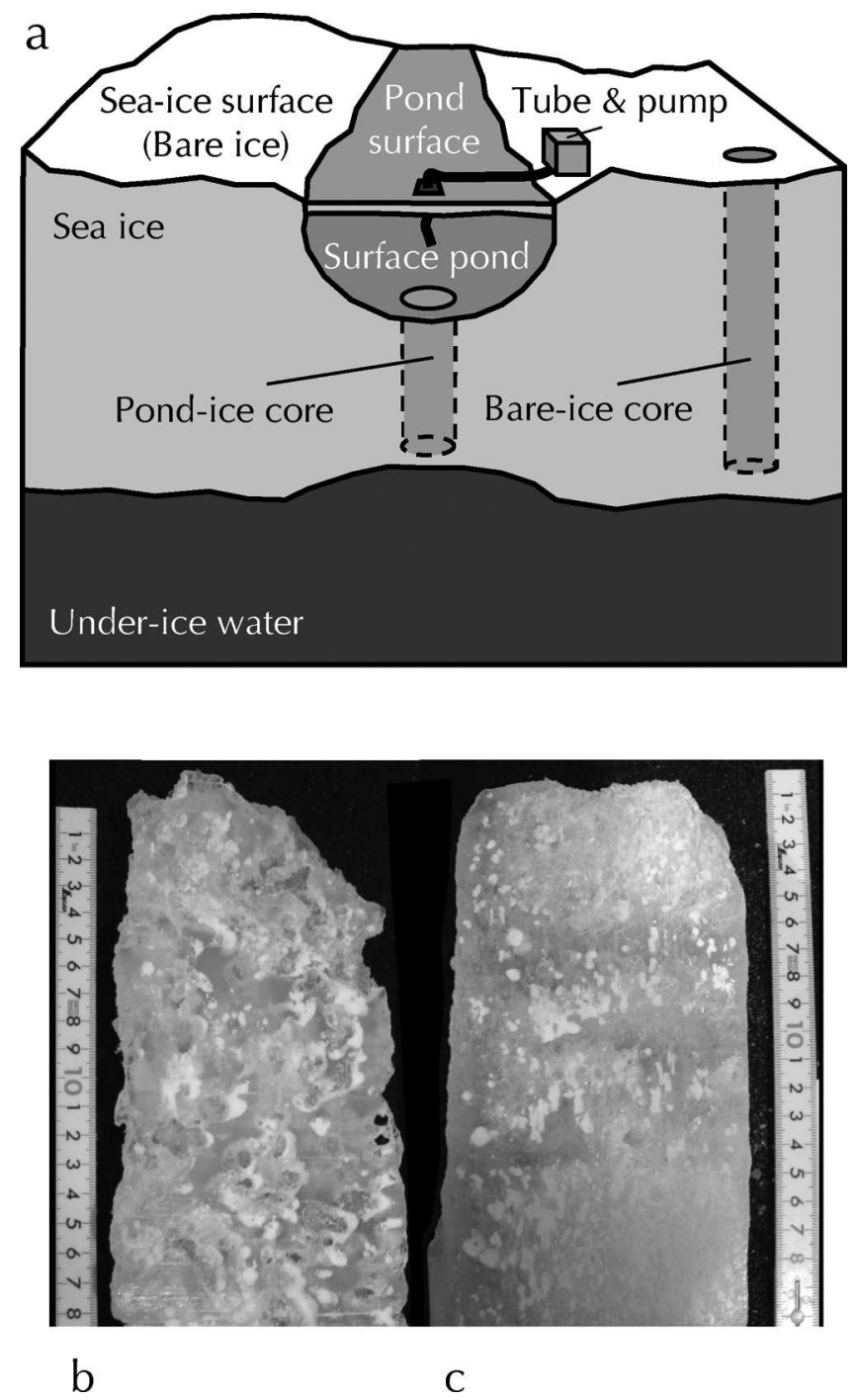

Fig. 2. (a) Schematic section of a surface pond in the sea ice, illustrating the sampling of surface pond water and pond-ice and bare-ice core collection. (b, c) Photographs of the top portions of the split ice cores in transmitted light: (b) pond-ice core and (c) bare-ice core.

(Eiken Chemical Co. Ltd, Tokyo, Japan) for measurement of inorganic nutrient concentrations. A saturated mercuric chloride $\left(\mathrm{HgCl}_{2}\right)$ solution $(200 \mu \mathrm{L})$ was added to the DIC samples to stop biological activity. Samples were stored in a

Table 1. Surface pond width, length, area, depth and ice thickness at the top of the pond. nm: not measured

\begin{tabular}{lrrrcc}
\hline Pond No. & Width & Length & Area & Depth & Ice thickness \\
& $\mathrm{m}$ & $\mathrm{m}$ & $\mathrm{m}^{2}$ & $\mathrm{~m}$ & $\mathrm{~m}$ \\
\hline P1 & 7.5 & 4.9 & 28.9 & 0.54 & 0.05 \\
P2 & 13.0 & 3.8 & 36.5 & 0.50 & $\mathrm{~nm}$ \\
P3 & 5.5 & 4.2 & 17.4 & 0.55 & $\mathrm{~nm}$ \\
P4 & 7.3 & 2.0 & 10.9 & 0.45 & 0.20 \\
P5 & 8.2 & 5.0 & 27.5 & 0.70 & 0.06 \\
P6 & 14.5 & 5.5 & 53.6 & $\mathrm{~nm}$ & 0.09 \\
P7 & 23.0 & 6.0 & 67.5 & $\mathrm{~nm}$ & 0.10 \\
P8 & 5.0 & 1.0 & 4.1 & 0.17 & $\mathrm{~nm}$ \\
P9 & 3.0 & 3.0 & 5.9 & 0.20 & $\mathrm{~nm}$ \\
& & & & & \\
\hline
\end{tabular}



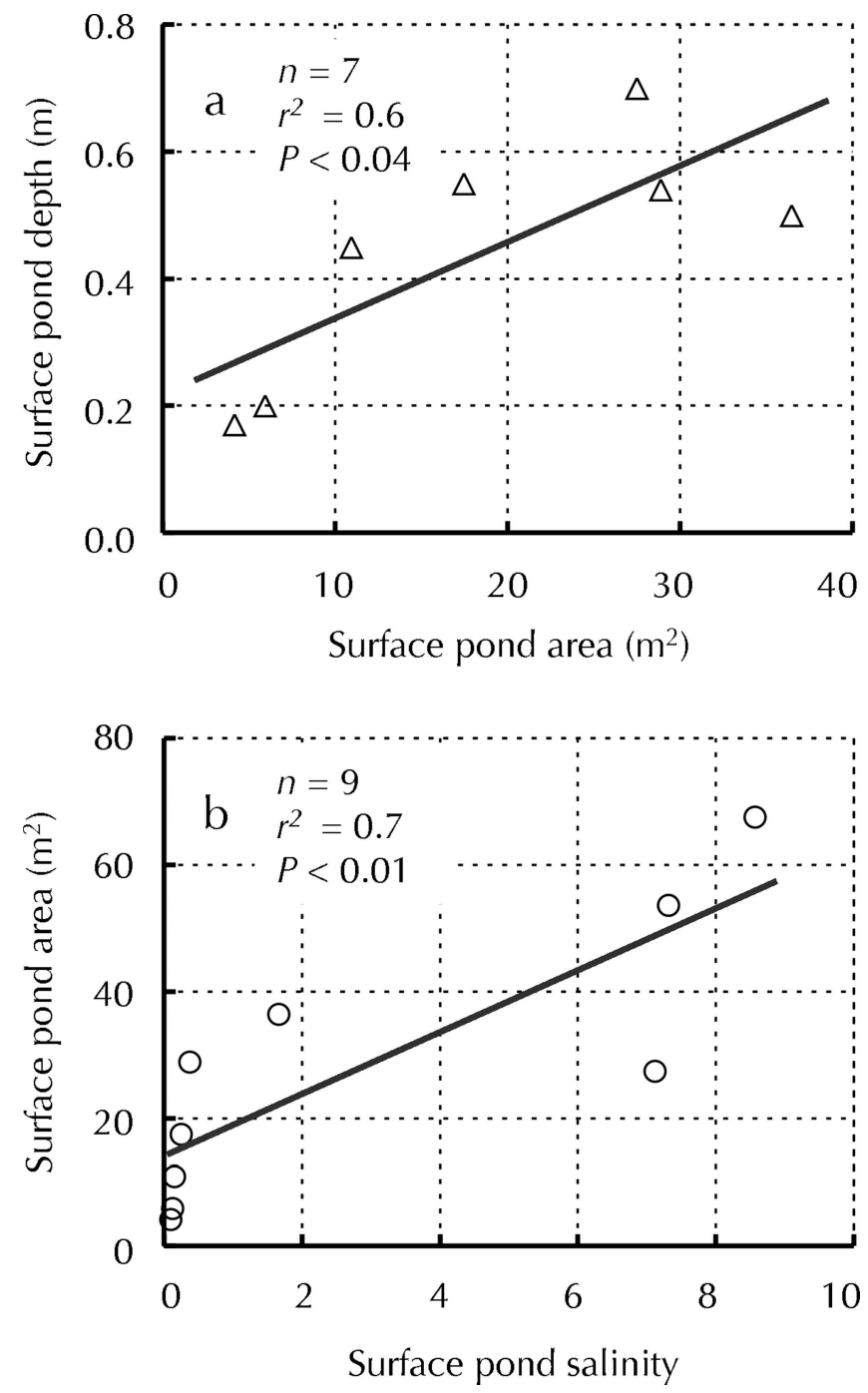

Fig. 3. Relationships between (a) surface pond depth and area and (b) surface pond area and salinity.

refrigerator $\left(+4^{\circ} \mathrm{C}\right)$ until measurement of salinity and DIC, and in a freezer $\left(-30^{\circ} \mathrm{C}\right)$ until measurement of nutrient concentrations. Samples for Chl-a measurement were immediately filtered through a $25 \mathrm{~mm}$ Whatman GF/F filter in the laboratory, which was near the sampling station. Chlorophyll pigments on the filters were then extracted with dimethylformamide (Suzuki and Ishimaru, 1990) for 24 hours at approximately $-80^{\circ} \mathrm{C}$.

Sea-ice cores and under-ice water were also collected during the study period. One ice core was collected from the ice beneath a surface pond (pond-ice core) and another from a bare-ice site near the surface pond (bare-ice core) (Fig. 2a). Details of methods for sea-ice core sampling and under-ice water sampling, and of the analytical procedures used to determine the physical and chemical properties of the core and water samples, are given in the Appendix.

The temperature of surface pond water was measured at $0.3 \mathrm{~m}$ depth in each surface pond, and that of under-ice water was measured at 1 and $7 \mathrm{~m}$ below the bottom of the sea ice with a needle-type temperature sensor (Testo 110 NTC, Brandt Instruments, Inc., Prairieville, LA, USA) at each sampling time. In addition, a thermistor probe (TR-5106, T\&D Corp., Nagano, Japan) and logger (RTR-52A, T\&D Corp.) were installed in surface pond $\mathrm{P} 1$ at $0.3 \mathrm{~m}$ depth to monitor daily variations in the water temperature from 30 January to 5 February 2010.

Surface dimensions of surface ponds were measured with a tape measure. Areas were then calculated with ImageJ software version $1.43 \mathrm{u}$ (W. Rasband, National Institutes of Health, Bethesda, MD, USA; http://rsb.info.nih.gov/ij). To measure the depth distribution, the surface was divided into a grid (0.5-1.0 m). At each gridpoint, a $0.05 \mathrm{~m} \times 0.05 \mathrm{~m}$ hole in the thin ice at the surface was made with a hand-saw, and surface pond depth was measured with a ruler. The thickness of the thin ice at each point was also measured.

\section{RESULTS}

\section{Surface pond dimensions}

Surface pond dimensions are shown in Table 1. Most surface ponds were relatively long and narrow (Table 1). Their areas varied greatly and ranged from 4.1 to $67.5 \mathrm{~m}^{2}$. Maximum depth ranged from 0.17 to $0.70 \mathrm{~m}$, and correlated with surface pond area $\left(n=7, r^{2}=0.6, p<0.04\right)$ (Fig. 3). In addition, surface pond area was correlated with salinity $\left(n=9, r^{2}=0.7, p<0.01\right)$. Bathymetric mapping of depth distributions (not shown) showed that the surface ponds had basin structures.

\section{Daily surface pond temperature variations}

Time series of surface pond water temperature, solar radiation and air temperature are shown in Figure 4. Surface pond temperatures fluctuated from +0.0 to $+1.4^{\circ} \mathrm{C}$ on a daily cycle, in synchrony with the fluctuations in solar radiation rather than air temperature.

\section{Biogeochemical properties of surface pond water and under-ice water}

Table 2 shows the results of the temperature, salinity, Chl-a concentration, and DIC and nutrient concentration measurements of surface pond water and under-ice water. In general, the temperatures of the surface pond water were higher than those of the under-ice water. Salinity and DIC and nutrient concentrations in surface pond water were much lower than those in under-ice water, whereas Chl-a concentrations in surface pond water were lower than or the same as those in under-ice water.

Relationships between biogeochemical parameters (DIC and nutrient concentrations) and salinity in surface pond and under-ice water are shown in Figure 5. In general, DIC, $\mathrm{NO}_{3}+\mathrm{NO}_{2}$ and $\mathrm{PO}_{4}$ concentrations in surface pond water were below the dilution line (Fig. $5 \mathrm{a}-\mathrm{C}$ ), except for $\mathrm{PO}_{4}$ concentrations at low salinity $(<1.7)$, which were above the dilution line (Fig. 5c). $\mathrm{NO}_{3}+\mathrm{NO}_{2}$ concentrations were depleted in surface pond water (Fig. 5b). No enrichment or depletion with respect to the dilution line was observed in surface pond $\mathrm{SiO}_{2}$ concentrations (Fig. 5d).

\section{Comparisons of physico-chemical properties between the pond-ice and the bare-ice core}

Photographs of the pond-ice and bare-ice core sections (Fig. $2 b$ and c) showed remarkable differences: unlike the bare-ice core, the pond-ice core contained many voids and had an irregular edge. These results indicate that the pondice core was more porous than the bare-ice core.

Figure 6 shows depth profiles of bulk ice density and salinity in the pond-ice and bare-ice cores. Bulk ice density 


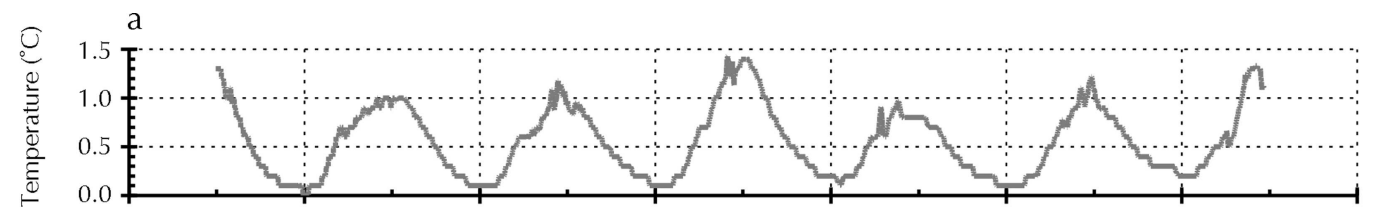

$\mathrm{b}$
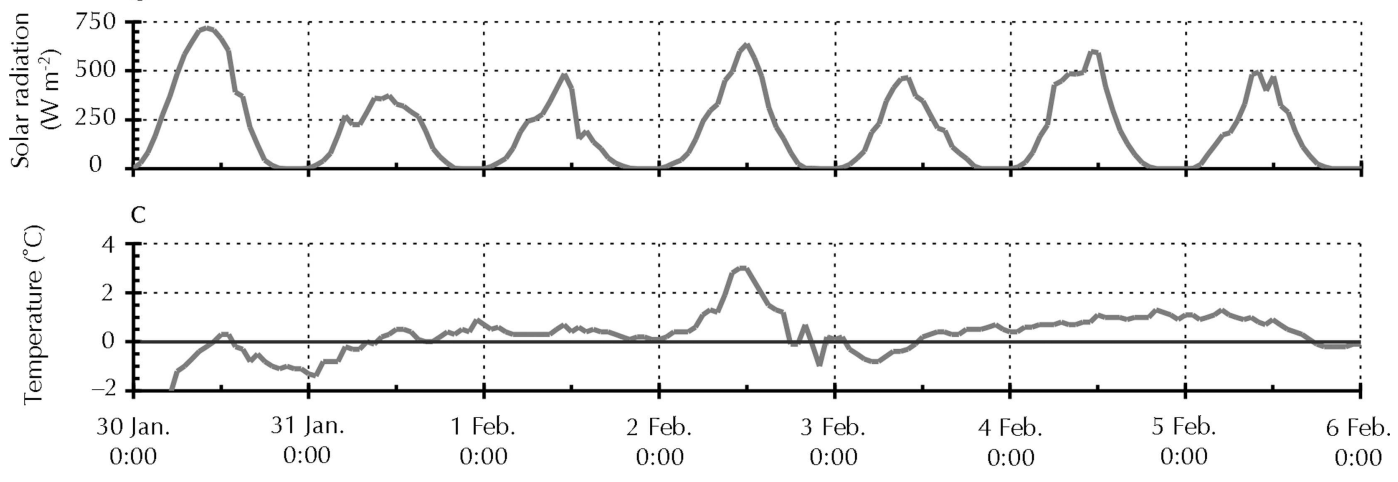

Date and time (UTC)

Fig. 4. Time series of (a) surface pond $\mathrm{P} 1$ water temperature, (b) solar radiation and (c) air temperature. Solar radiation and air temperature were measured at Syowa station, $<1 \mathrm{~km}$ from our surface pond study area (Japan Meteorological Agency; http://www.data.jma.go.jp/obd/ stats/etrn/index.php).

was $525.9 \pm 64.5 \mathrm{~kg} \mathrm{~m}^{-3}$ in the pond-ice core and $825.1 \pm 64.6 \mathrm{~kg} \mathrm{~m}^{-3}$ in the bare-ice core and increased with depth in both cores (Fig. 6a). Bulk ice salinity tended to increase with depth in the bare-ice core, from zero at the top, to 1.6 at the bottom of the sea ice (Fig. 6b). In the pondice core, bulk ice salinity was lower at each depth than the corresponding value in the bare-ice core (Fig. 6b).

Depth profiles of bulk Chl-a and nutrient concentrations in the pond-ice and bare-ice cores are shown in Figure 7. The bulk Chl-a concentration in the bare-ice core was close to zero at the top and in the middle of the sea ice, but at the bottom it increased to $6.5 \mu \mathrm{g} \mathrm{L}^{-1}$. In the pond-ice core, the bulk ice Chl-a concentration at each depth was lower than that at the corresponding depth in the bare-ice core (Fig. 7a). Bulk $\mathrm{NO}_{3}+\mathrm{NO}_{2}$ concentrations were almost constant $\left(1.2 \pm 0.5 \mu \mathrm{mol} \mathrm{L}^{-1}\right)$ in the sea ice of the bare-ice core, whereas in the pond-ice core they were clearly higher and tended to decrease with depth, from a maximum of $9.6 \mu \mathrm{mol} \mathrm{L}^{-1}$ near the top of the sea ice to a minimum of $3.2 \mu \mathrm{mol} \mathrm{L}^{-1}$ near the bottom (Fig. $7 \mathrm{~b}$ ). In contrast, the bulk $\mathrm{PO}_{4}$ and $\mathrm{SiO}_{2}$ concentrations tended to increase with depth in both cores, and their profiles were similar to that of the bulk Chl-a concentration. Bulk $\mathrm{PO}_{4}$ and $\mathrm{SiO}_{2}$ concentrations in the pond-ice core were lower, however, than those at corresponding depths in the bare-ice core (Fig. 7c and d).

\section{DISCUSSION}

The surface ponds examined were on the downwind side of an island and an iceberg, where snow accumulation was minimal, resulting in the formation of a bare-ice region. Snow is a good reflector, whereas bare ice is an effective

Table 2. Temperature, salinity, Chl-a concentrations, DIC and nutrients concentrations for surface pond and under-ice water. ns: not sampled

\begin{tabular}{|c|c|c|c|c|c|c|c|c|c|}
\hline Pond No. & Sample & Date (2010) & $\begin{array}{l}\text { Temp. } \\
{ }^{\circ} \mathrm{C}\end{array}$ & Salinity & $\begin{array}{l}\text { Chl a } \\
\mu \mathrm{gL}^{-1}\end{array}$ & $\begin{array}{c}\text { DIC } \\
\mu \mathrm{mol} \mathrm{L}^{-1}\end{array}$ & $\begin{array}{c}\mathrm{NO}_{3}+\mathrm{NO}_{2} \\
\mu \mathrm{mol} \mathrm{L}^{-1}\end{array}$ & $\begin{array}{c}\mathrm{PO}_{4} \\
\mu \mathrm{mol} \mathrm{L}^{-1}\end{array}$ & $\begin{array}{c}\mathrm{SiO}_{2} \\
\mu \mathrm{mol} \mathrm{L}^{-1}\end{array}$ \\
\hline P1 & Surface pond water & 29 Jan & -0.8 & 0.1 & 0.0 & 37.7 & 0.1 & 0.0 & 1.2 \\
\hline P1 & Surface pond water & 31 Jan & +0.9 & 0.1 & 0.0 & 33.5 & 0.0 & 0.0 & 0.9 \\
\hline P1 & Surface pond water & 2 Feb & +1.8 & 0.1 & 0.0 & 32.5 & 0.0 & 0.0 & 0.9 \\
\hline P1 & Surface pond water & 5 Feb & +0.9 & 0.4 & 0.1 & 50.8 & 0.0 & 0.1 & 1.5 \\
\hline P1 & Under-ice water (1 m) & 5 Feb & -0.9 & 32.3 & 0.8 & 1925.2 & 24.0 & 1.7 & 63.3 \\
\hline P1 & Under-ice water (7 m) & 5 Feb & -0.3 & 29.8 & 0.5 & 1802.1 & 21.1 & 1.6 & 57.1 \\
\hline P2 & Surface pond water & 5 Feb & +0.1 & 1.7 & 0.0 & 108.3 & 0.1 & 0.1 & 4.5 \\
\hline P3 & Surface pond water & 5 Feb & +0.0 & 0.2 & 0.2 & 94.3 & 0.1 & 0.3 & 1.4 \\
\hline P4 & Surface pond water & 5 Feb & +0.0 & 0.2 & 0.1 & 35.2 & 0.1 & 0.3 & 1.0 \\
\hline P5 & Surface pond water & 5 Feb & -0.3 & 7.1 & 0.7 & 313.5 & 0.2 & 0.2 & 14.1 \\
\hline P6 & Surface pond water & 5 Feb & +0.4 & 7.3 & 0.5 & 301.8 & 0.2 & 0.3 & 14.1 \\
\hline P7 & Surface pond water & 5 Feb & +0.0 & 8.6 & 0.4 & 331.3 & 0.2 & 0.3 & 15.8 \\
\hline P9 & Surface pond water & 30 Jan & -0.1 & 0.1 & 0.0 & ns & 0.0 & 0.1 & 1.1 \\
\hline P9 & Under-ice water (1 m) & 30 Jan & -0.9 & 33.0 & 0.2 & ns & 24.5 & 1.7 & 63.4 \\
\hline P9 & Under-ice water (7 m) & 30 Jan & +0.0 & 29.7 & 0.2 & ns & 20.6 & 1.5 & 55.8 \\
\hline
\end{tabular}



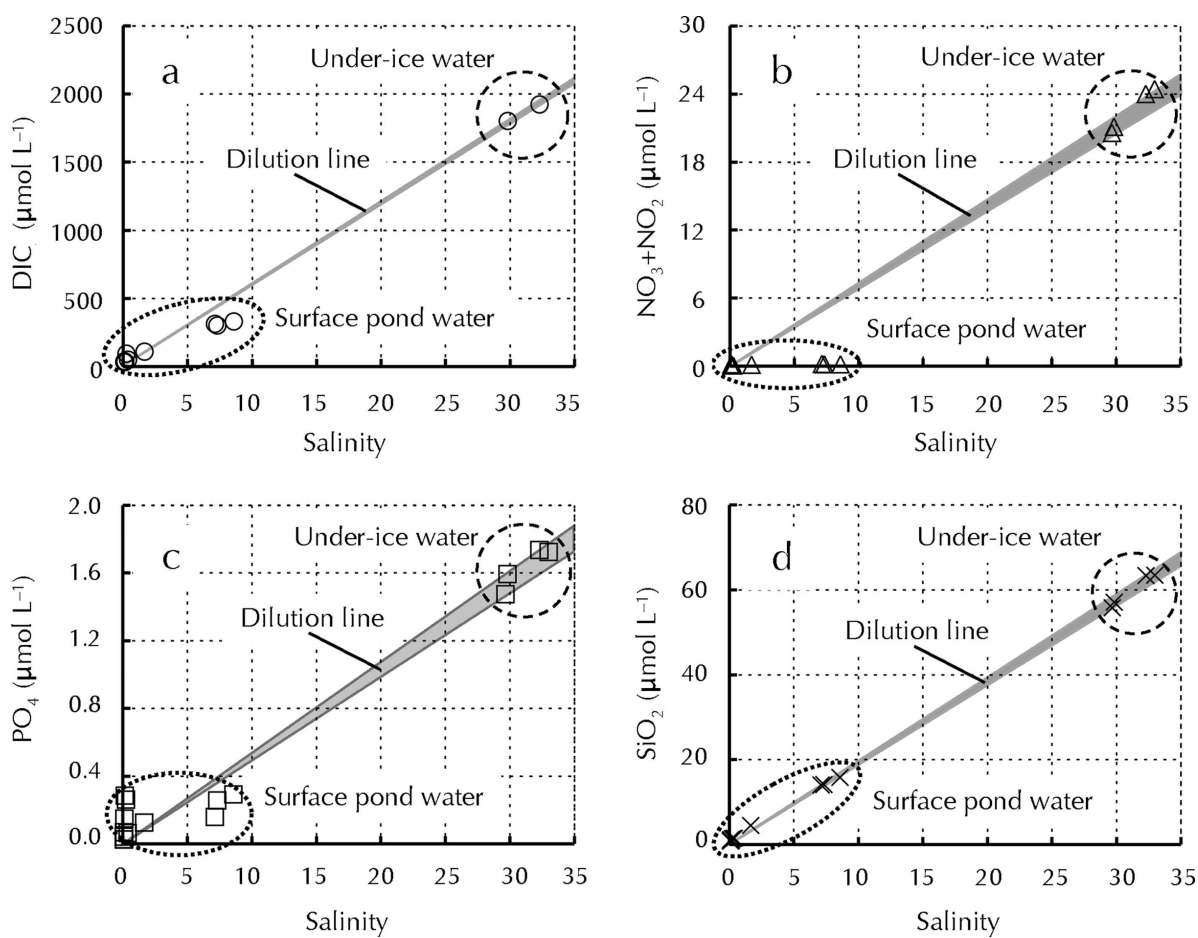

Fig. 5. Plots of (a) DIC, (b) $\mathrm{NO}_{3}+\mathrm{NO}_{2}$, (c) $\mathrm{PO}_{4}$ and (d) $\mathrm{SiO}_{2}$ concentrations versus salinity for surface pond water and under-ice water. Shaded areas indicate dilution lines predicted from values in under-ice water.

absorber, of solar radiant energy (Fetterer and Untersteiner, 1998). Thus, surface ponds tend to form on bare sea ice. Surface ponds form every year in summer at this study site (personal communication from S. Kudo, 2009). Furthermore, in Lützow-Holm Bay, melting of multi-year fast ice over a wide area $(\sim 10 \mathrm{~km})$ and the formation of surface ponds have been observed by satellite (Enomoto and others, 2002).

We examined surface ponds that varied greatly in size and other characteristics, and obtained a wide range of information about their geometry, physics, chemistry and biology. Nearly all the studied surface ponds were approximately rectangular (Table 1), with their longer dimension aligned with the dominant northeast-southwest wind direction in this area. Snow surface conditions are changed by wind, causing sea-ice surface roughness (e.g. sastrugi) (Goodwin, 1990; Sturm, 2009). Thus, these observations suggest that the changes in snow depth changed the melting rate of the snow, and that the surface ponds formed according to the snow surface roughness. Surface ponds were also formed by the flooding of ice-floe surface, leading to further snow and ice melt at the surface (Ackley and Sullivan, 1994). The surface pond salinity varied widely from almost zero to sea-water values, depending on the dominant process for surface pond formation (Ackley and Sullivan, 1994).
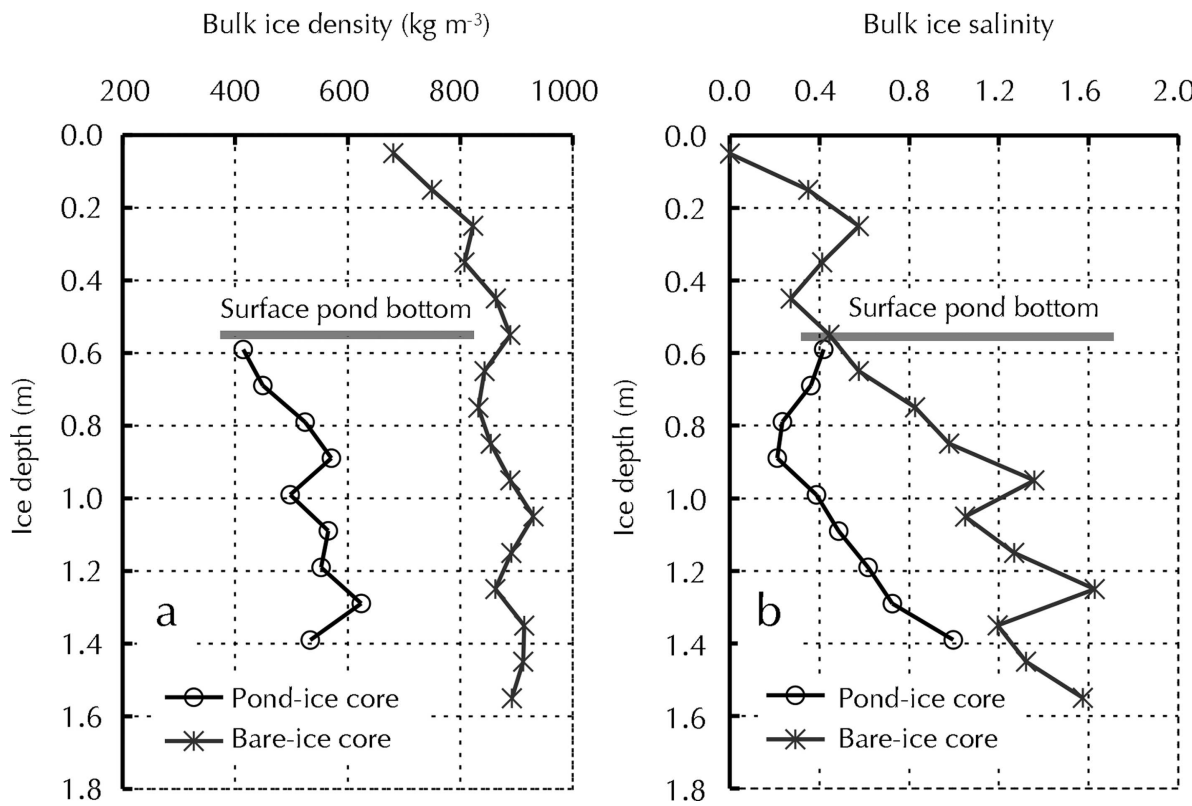

Fig. 6. Depth profiles of bulk ice (a) density and (b) salinity in the pond-ice and bare-ice cores. 
Bulk ice Chl a $\left(\mu \mathrm{g} \mathrm{L}^{-1}\right)$

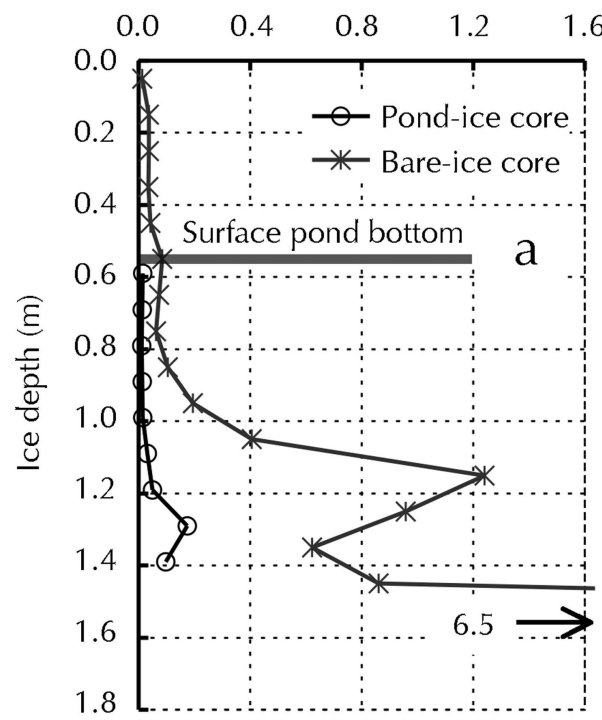

Bulk ice $\mathrm{PO}_{4}(\mu \mathrm{mol} \mathrm{L}-1)$

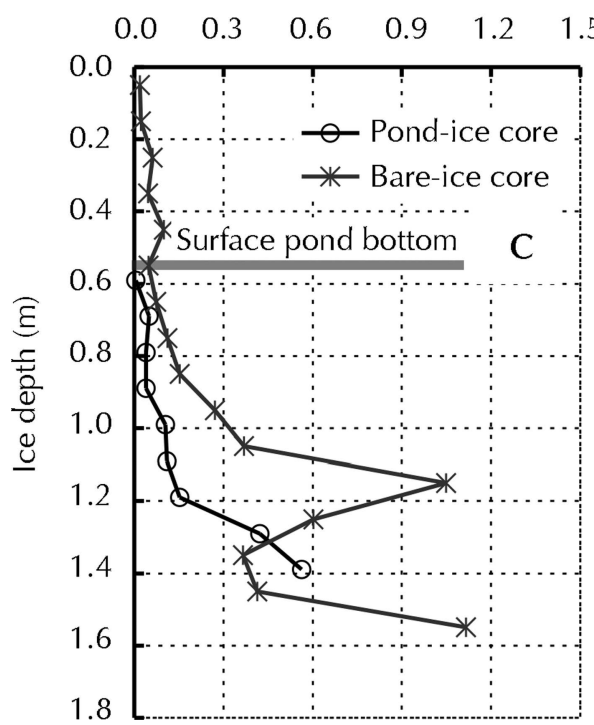

Bulk ice $\mathrm{NO}_{3}+\mathrm{NO}_{2}(\mu \mathrm{mol} \mathrm{L}-1)$

\section{6}

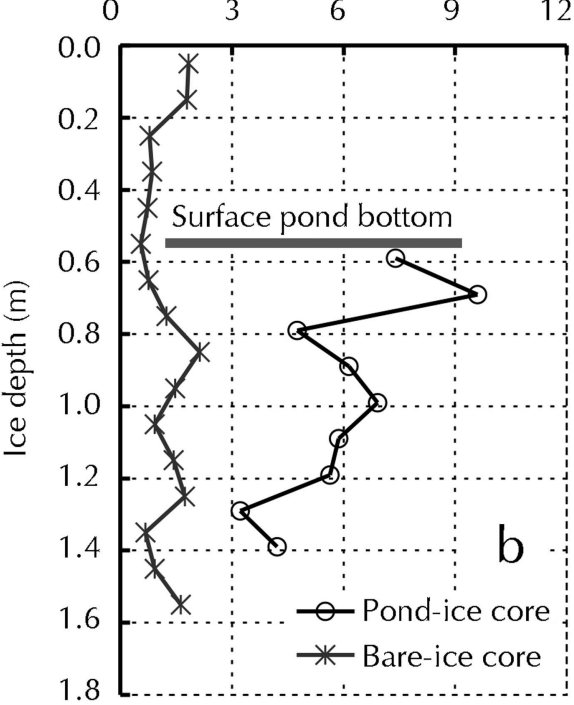

Bulk ice $\mathrm{SiO}_{2}\left(\mu \mathrm{mol} \mathrm{L}^{-1}\right)$

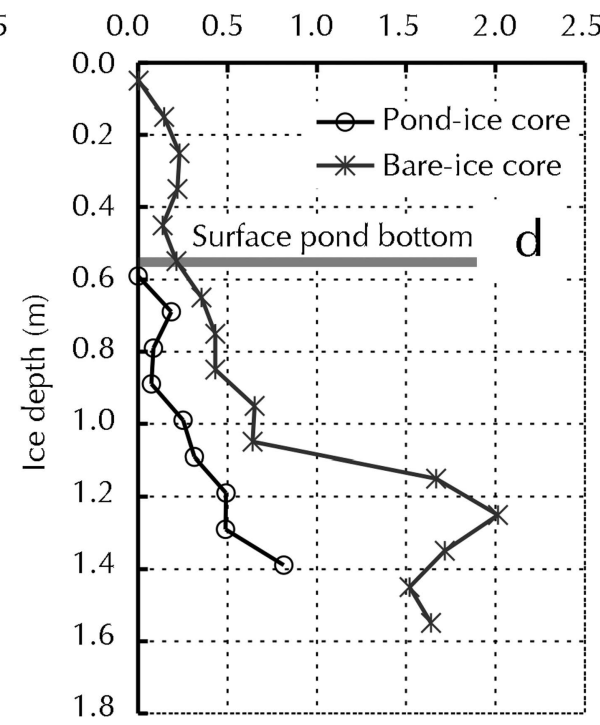

Fig. 7. Depth profiles of bulk ice (a) Chl a, (b) $\mathrm{NO}_{3}+\mathrm{NO}_{2}$, (c) $\mathrm{PO}_{4}$ and (d) $\mathrm{SiO}_{2}$ concentrations in the pond-ice and bare-ice cores.

Surface pond area showed good correlation with both depth and salinity (Fig. 3), suggesting that it might be possible to predict surface pond depth and salinity from pond area information obtained from the images (pictures) taken from the ship, helicopter and satellite. Surface pond salinity increased with area (Fig. 3b), suggesting that it also increased with depth. Because the sea ice sampled from beneath a surface pond (pond-ice core) was more porous than that in the core collected outside the surface pond (bare-ice core) (Figs 2b and c and 6a), water likely passes from the surface pond down through the porous sea ice, and under-ice water probably moves up through the sea ice into the surface pond (Eicken and others, 2002), so the extent of this exchange will depend on the thickness of the sea ice beneath the surface pond (core length), and thus on surface pond depth.

The results of the long-term measurement of surface pond temperature suggest that it varied with solar radiation rather than with air temperature (Fig. 4), indicating that solar radiation penetrates into the surface ponds through the thin ice cover, raising the water temperature in the surface pond to above the freezing point. Solar radiant energy absorbed by the meltwater will then melt additional ice. Surface ponds have been observed to increase in size and deepen, and to merge with adjacent surface ponds (Perovich, 1999; Eicken and others, 2002). These processes have been successfully modeled by a one-dimensional thermodynamic surface-pond-sea-ice model (Taylor and Feltham, 2004).

Comparison of surface pond water properties with dilution lines (Fig. 5) suggested that DIC and nutrients $\left(\mathrm{NO}_{3}+\mathrm{NO}_{2}\right.$ and $\left.\mathrm{PO}_{4}\right)$ were removed by biological productivity from the water during pond formation. $\mathrm{NO}_{3}+\mathrm{NO}_{2}$ concentrations were completely depleted (see Fig. 5b), suggesting that nitrogen was a limiting factor of biological productivity, even though other nutrients $\left(\mathrm{PO}_{4}\right.$ and $\left.\mathrm{SiO}_{2}\right)$ were available (Fig. $5 \mathrm{c}$ and d). The nitrate depletions were also found in the surface ponds (Kennedy and others, 2002) and surface gap layer in the Weddell Sea (Papadimitriou and others, 2009).

The algal production in surface ponds during pond formation was examined based on the changes in the $\mathrm{NO}_{3}+\mathrm{NO}_{2}$ concentrations. If $\mathrm{NO}_{3}+\mathrm{NO}_{2}$ concentrations 
behaved conservatively during ice and surface pond formation, the initial $\mathrm{NO}_{3}+\mathrm{NO}_{2}$ concentrations could be calculated from the relationships between the $\mathrm{NO}_{3}+\mathrm{NO}_{2}$ concentrations and salinity shown in Figure $5 \mathrm{~b}$ (dilution line). Because $\mathrm{NO}_{3}+\mathrm{NO}_{2}$ concentrations in surface ponds were depleted over the sampling period, the initial $\mathrm{NO}_{3}+$ $\mathrm{NO}_{2}$ concentrations $\left(0.0-6.1 \mu \mathrm{mol} \mathrm{L}{ }^{-1} ; \mathrm{NO}_{3}+\mathrm{NO}_{2}\right.$ concentration above the dilution line for each salinity in Fig. 5b) could be used as the measure for algal production during surface pond formation. Algal production (as particulate organic carbon (POC)) was calculated using a Redfield C : N molar ratio of 6.6 , and results indicated that $0.0-40.3 \mu \mathrm{mol}$ of POC were produced by algal production during pond formation. This value might be a lower limit because it was assumed that there was no exchange of water between surface ponds and the under-ice. Earlier studies indicated that the salinities of surface ponds (7-30; Kennedy and others, 2002) and gap layers (20-33; Papadimitriou and others, 2009) were higher than those in the surface pond in this study (0.1-8.6; Table 2). Therefore, the mixing with under-ice/ambient water occurred frequently and supplied the nutrients for the algal production, although nitrate was depleted in the water (Kennedy and others, 2002). This is probably one reason why Chl-a concentrations in the surface pond in this study were so much lower than those in previous studies (Kennedy and others, 2002; Papadimitriou and others, 2009). It would be reasonable to assume that the surface melting is the dominant process for formation of surface ponds in this study area.

In the pond-ice core, the trend of the bulk ice $\mathrm{NO}_{3}+\mathrm{NO}_{2}$ concentration profile differed from those of the bulk ice $\mathrm{PO}_{4}$ and $\mathrm{SiO}_{2}$ concentration profiles (Fig. 7). Bulk ice $\mathrm{NO}_{3}+\mathrm{NO}_{2}$ concentrations in the upper part of the pond-ice core were high (up to $9.6 \mu \mathrm{mol} \mathrm{L}^{-1}$ ), and much higher than the concentration in surface pond water (Figs $5 \mathrm{~b}$ and $7 \mathrm{~b}$; Table 2). Furthermore, $\mathrm{NO}_{3}+\mathrm{NO}_{2}$ concentrations in the pond-ice core were above the dilution lines (not shown). These results suggest that remineralization of organic matter occurred at the bottom of the surface pond (upper part of the pond-ice core). The particulate matter, formed as a result of biological productivity in the surface pond, sank to the bottom of the surface pond, where the organic matter was remineralized. In the Antarctic sea ice, the highest bacterial production was found in saline ponds on the surface of floes and in pore water in the interior of floes throughout the ice floes (Kottmeier and Sullivan, 1990). Therefore, high dissolved organic carbon was measured in surface ponds in the Weddell Sea during summer (Herborg and others, 2001). In addition, Schnack-Schiel and others (2001) found grazers in Antarctic surface ponds. The grazers are contributed and influenced by the biogeochemical cycles in the surface ponds (Schnack-Schiel and others, 2001).

The pond-ice core was porous and characterized by low bulk ice density (Figs $2 \mathrm{~b}$ and $\mathrm{c}$ and 6a), suggesting high porosity and permeability. Therefore, particulate and dissolved components could easily percolate downward through the ice. Because high amounts of $\mathrm{NO}_{3}+\mathrm{NO}_{2}$ were preserved in the pond ice (Fig. 7b), the depletion of $\mathrm{NO}_{3}+\mathrm{NO}_{2}$ probably occurred in the surface pond water (Fig. 5b; Table 2).

The trends of the bulk ice $\mathrm{PO}_{4}$ and $\mathrm{SiO}_{2}$ profiles in the pond-ice core increased with depth, especially below $\sim 1 \mathrm{~m}$ depth, similar to the bulk ice salinity trend, and the $\mathrm{PO}_{4}$ and $\mathrm{SiO}_{2}$ concentrations were generally lower than those in the bare-ice core (Figs $6 \mathrm{~b}$ and $7 \mathrm{c}$ and $\mathrm{d}$ ). These results suggest that the behaviors of $\mathrm{PO}_{4}$ and $\mathrm{SiO}_{2}$ were the same as that of salinity. No clear effect of the remineralization of organic matter on the $\mathrm{PO}_{4}$ concentration in the pond-ice core was observed (Fig. 7c). However, excess (enrichment of) $\mathrm{PO}_{4}$ was observed at very low salinity in the surface pond water (Fig. 5c), suggesting that some mineralized $\mathrm{PO}_{4}$ at the bottom of the surface pond was diffused into the surface pond water. The low bulk ice $\mathrm{SiO}_{2}$ concentration in the pond-ice core (Fig. 7 d) and the salinity- $\mathrm{SiO}_{2}$ concentration relationship in the surface pond water (Fig. $5 \mathrm{~d}$ ) suggested that biogenic opal (diatom) production and dissolution were balanced, or that the contribution of biogenic opal to the variation in the $\mathrm{SiO}_{2}$ concentration in the pond ice and the surface pond water was minor because it is said that photosynthetic flagellates, which do not utilize $\mathrm{SiO}_{2}$ during photosynthesis, dominated in the upper part of the Antarctic fast sea ice in McMurdo Sound (Stoecker and others, 1998, 2000) and near Davis Station, East Antarctica (Thomson and others, 2006).

Bulk ice Chl-a concentrations in the bare-ice core were high in the lower part of the core (Fig. 7a). It is well known that assemblages of ice algae occur at the bottom of sea ice and contribute significantly to primary production (Legendre and others, 1992; Arrigo and others, 2009). In contrast to the bare-ice core, Chl-a concentrations throughout the pond-ice core were low. The bottom concentration of $0.1 \mu \mathrm{g} \mathrm{L}^{-1}$ was approximately $1 / 65$ that of the bare-ice core $\left(6.5 \mu \mathrm{g} \mathrm{L}^{-1}\right)$. These results suggest that surface pond formation led to a decrease in the Chl-a concentration of the sea ice. This decrease suggests that meltwater flushes the ice algae (which contain the $\mathrm{Chl}$ a) out of the porous sea ice into the under-ice water, and that the removal of ice algae living at the bottom of the sea ice occurred due to ice melting. Comparisons of the different lengths of the pond-ice and bare-ice cores with surface pond depth suggest that ice melting occurred at the bottom of the pond-ice more than the bare-ice core over the sampling period.

The physico-chemical properties of ice cores (Figs $2 \mathrm{~b}$ and $c$ and 6 and 7) showed remarkable differences between the pond-ice and the bare-ice core. However, the results obtained might be affected by short-range spatial variability in sea-ice properties (e.g. Granskog and others, 2004). No data were collected that would allow the heterogeneity of these sea-ice parameters to be evaluated. Therefore, it might be difficult to extrapolate the significance of the findings clearly. For future study, replicate samplings for sea-ice cores are needed.

\section{ACKNOWLEDGEMENTS}

We express our heartfelt thanks to all members of the 51 st Japanese Antarctic Research Expedition for supporting the fieldwork. We thank Y.W. Watanabe for providing the instrument for DIC analysis, and J. Kanda and S. Yasui for the nutrient analyses.

\section{REFERENCES}

Ackley, S.F. and C.W. Sullivan. 1994. Physical controls on the development and characteristics of Antarctic sea ice biological communities - a review and synthesis. Deep-Sea Res., 41(10), 1583-1604.

Arrigo, K.R., T. Mock and M.P. Lizotte. 2009. Primary producers and sea ice. In Thomas, D.N. and G.S. Dieckmann, eds. Sea ice. Oxford, Wiley-Blackwell, 283-325. 
Ebert, E.E. and J.A. Curry. 1993. An intermediate one-dimensional thermodynamic sea ice model for investigating ice-atmosphere interactions. J. Geophys. Res., 98(C6), 10,085-10,109.

Eicken, H. 1994. Structure of under-ice melt ponds in the central Arctic and their effect on the sea-ice cover. Limnol. Oceanogr., 39(3), 682-694.

Eicken, H., H.R. Krouse, D. Kadko and D.K. Perovich. 2002. Tracer studies of pathways and rates of meltwater transport through Arctic summer sea ice. J. Geophys. Res., 107(C10), 8046. (10.1029/2000JC000583.)

Enomoto, H., F. Nishio, H. Warashina and S. Ushio. 2002. Satellite observation of melting and break-up of fast ice in Lützow-Holm Bay, East Antarctica. Polar Meteorol. Glaciol., 16, 1-14.

Fetterer, F. and N. Untersteiner. 1998. Observations of melt ponds on Arctic sea ice. J. Geophys. Res., 103(C11), 24,821-24,835.

Garrison, D.L. and K.R. Buck. 1986. Organism losses during ice melting: a serious bias in sea ice community studies. Polar Biol., 6(4), 237-239.

Goodwin, I.D. 1990. Snow accumulation and surface topography in the katabatic zone of eastern Wilkes Land, Antarctica. Antarct. Sci., 2(3), 235-242.

Gradinger, R. 1996. Occurrence of an algal bloom under Arctic pack ice. Mar. Ecol. Progr. Ser., 131, 301-305.

Granskog, M.A., M. Leppäranta, T. Kawamura, J. Ehn and K. Shirasawa. 2004. Seasonal development of the properties and composition of landfast sea ice in the Gulf of Finland, the Baltic Sea. J. Geophys. Res., 109(C2), C02020. (10.1029/ 2003JC001874.)

Haas, C., D.N. Thomas and J. Bareiss. 2001. Surface properties and processes of perennial Antarctic sea ice in summer. J. Glaciol., 47(159), 613-625.

Herborg, L.-M., D.N. Thomas, H. Kennedy, C. Haas and G.S. Dieckmann. 2001. Dissolved carbohydrates in Antarctic sea ice. Antarct. Sci., 13(2), 119-125.

Johnson, K.M., A.E. King and J.M. Sieburth. 1985. Coulometric $\mathrm{TCO}_{2}$ analyses for marine studies; an introduction. Mar. Chem., 16(1), 61-82.

Joint Global Ocean Flux Study (JGOFS). 1996. Protocols for the Joint Global Ocean Flux Study core measurements. Bergen, Centre for Studies of Environment and Resources. JGOFS Core Project Office. (JGOFS Report 19.)

Kennedy, H., D.N. Thomas, G. Kattner, C. Haas and G.S. Dieckmann. 2002. Particulate organic matter in Antarctic summer sea ice: concentration and stable isotopic composition. Mar. Ecol. Progr. Ser., 238, 1-13.

Kottmeier, S.T. and C.W. Sullivan. 1990. Bacterial biomass and production in pack ice of Antarctic marginal ice edge zones. Deep-Sea Res., 37(8), 1311-1330.

Legendre, L. and 9 others. 1992. Ecology of sea ice biota. 2. Global significance. Polar Biol., 12(3-4), 429-444.

Massom, R.A. and 12 others. 2001. Snow on Antarctic sea ice. Rev. Geophys., 39(3), 413-445.

Papadimitriou, S., D.N. Thomas, H. Kennedy, H. Kuosa and G.S. Dieckmann. 2009. Inorganic carbon removal and isotopic enrichment in Antarctic sea ice gap layers during early austral summer. Mar. Ecol. Progr. Ser., 386, 15-27.

Parsons, T.R., M. Takahashi and B. Hargrave. 1984. Biological oceanographic processes. Third edition. Oxford, Pergamon Press

Perovich, D.K. and 8 others. 1999. SHEBA: snow and ice studies, CD-ROM. Version 1.0. Hanover, NH, US Army Corps of Engineers. Cold Regions Research and Engineering Laboratory.

Perovich, D.K., T.C. Grenfell, B. Light and P.V. Hobbs. 2002. Seasonal evolution of the albedo of multiyear Arctic sea ice. J. Geophys. Res., 107(C10), 8044. (10.1029/2000JC000438.)

Rösel, A. and L. Kaleschke. 2011. Comparison of different retrieval techniques for melt ponds on Arctic sea ice from Landsat and MODIS satellite data. Ann. Glaciol., 52(57 Pt 2), 185-191.

Schnack-Schiel, S.B., D.N. Thomas, C. Haas, G.S. Dieckmann and R. Alheit. 2001. The occurrence of the copepods Stephos longipes (Calanoida) and Drescheriella glacialis (Harpacticoida) in summer sea ice in the Weddell Sea, Antarctica. Antarct. Sci., 13(2), 150-157.

Stoecker, D.K., D.E. Gustafson, M.M.D. Black and C.T. Baier. 1998. Population dynamics of microalgae in the upper land-fast sea ice at a snow-free location. J. Phycol., 34(1), 60-69.

Stoecker, D.K., D.E. Gustafson, C.T. Baier and M.M.D. Black. 2000. Primary production in the upper sea ice. Aquat. Microbial Ecol., 21(3), 275-287.

Sturm, M. 2009. Field techniques for snow observations on sea ice. In Eicken, H., R. Gradinger, M. Salganek, K. Shirasawa, D. Perovich and M. Leppäranta, eds. Field techniques for sea ice research. Fairbanks, AK, University of Alaska Press, 25-48.

Sturm, M. and R.A. Massom. 2010. Snow and sea ice. In Thomas, D.N. and G.S. Dieckmann, eds. Sea ice. Oxford, WileyBlackwell, 153-204.

Suzuki, R. and T. Ishimaru. 1990. An improved method for the determination of phytoplankton chlorophyll using $\mathrm{N}, \mathrm{N}$-dimethylformamide. J. Oceanogr. Soc. Jpn, 46(4), 190-194.

Taylor, P.D. and D.L. Feltham. 2004. A model of melt pond evolution on sea ice. J. Geophys. Res., 109(C12), C12007. (10.1029/2004JC002361.)

Thomson, P.G., A. McMinn, I. Kiessling, M. Watson and P.M. Goldsworthy. 2006. Composition and succession of dinoflagellates and chrysophytes in the upper fast ice of Davis Station, East Antarctica. Polar Biol., 29(4), 337-345.

Wadhams, P. 2000. Ice in the ocean. Amsterdam, etc., Gordon and Breach.

\section{APPENDIX}

\section{Sea-ice core and under-ice water sampling methods}

The sea-ice core was collected using an ice corer (Geo Tecs Co., Ltd., Chiba, Japan) with an internal diameter of $0.09 \mathrm{~m}$ from the bottom of P1 (pond-ice core) and from a site on the bare ice $5 \mathrm{~m}$ away from the edge of P1 (bare-ice core) on 2 February 2010 (Fig. 2a). The ice core for measurement of bulk ice density, salinity and nutrient concentrations was immediately placed in a polyethylene bag and kept horizontally in a cooler along with refrigerant to keep its temperature low and to minimize brine drainage from the core. After we returned to the laboratory, which was near the sampling station, the ice core was stored in a freezer at $-20^{\circ} \mathrm{C}$ until analysis. The core for measurement of the bulk ice $\mathrm{Chl}-\mathrm{a}$ concentration was sliced into $0.1 \mathrm{~m}$ thick sections at the sampling site, and the samples were placed in polyethylene cups. Upon arrival at the laboratory, the sections were placed in polyethylene cups with $150 \mathrm{~mL}$ of artificial sea water $(40 \mathrm{~g}$ $\mathrm{NaCl}$ in $1 \mathrm{~L}$ Milli-Q water) for melting, to avoid the loss of intracellular organic solute from cell rupture under osmotic stress (Garrison and Buck, 1986). Melted core samples of known volume were filtered in the same manner as the pond water samples and then stored until analysis.

Under-ice water samples were collected through ice-core holes with a Teflon water sampler (GL Science Inc., Tokyo, Japan) from 1 and $7 \mathrm{~m}$ below the bottom of the sea ice from two sites, $5 \mathrm{~m}$ away from the edge of P9 on 30 January 2010 and $5 \mathrm{~m}$ from the edge of P1 on 5 February 2010 (Table 2). Under-ice water samples were collected $\sim 30 \mathrm{~min}$ after the ice core was drilled to avoid the effects of disturbance caused by drilling. Samples were handled and stored in the same manner as the pond water samples.

\section{Sea-ice sample treatment}

In the cold room $\left(-20^{\circ} \mathrm{C}\right)$ of the Japan Maritime Self-Defense Force icebreaker Shirase, ice cores were split lengthwise into halves with an electric bandsaw, and photographs of the ice 
sections were taken using transmitted light. For measurement of bulk ice density, salinity and nutrient concentrations, the core was cut into $0.045 \mathrm{~m} \times 0.025 \mathrm{~m}$ rectangular cross sections, which were then sliced into $0.1 \mathrm{~m}$ thick sections. To determine the bulk ice density, the dimensions (for calculation of volume) and weight of each ice section were measured with a Vernier micrometer and weight scale, respectively. To avoid contamination during sampling and handling, the outer $0.003 \mathrm{~m}$ thick layer of the ice section was removed with a stainless-steel plane. Then the ice sample was put into a polyethylene bag and melted shortly before analysis at room temperature.

\section{Analytical procedures}

Salinities of surface pond water, melted ice samples and under-ice water were measured with a salinity analyzer (SAT-210, Toa Electronics Ltd, Tokyo, Japan). This was calibrated using International Association for the Physical Sciences of the Oceans standard sea water (P series; Ocean Scientific International Ltd, Havant, UK). The standard deviation for salinity calculated from 15 subsamples taken from a reference water sample $(S=10.00)$ was 0.03 .

The DIC concentrations in the surface pond water and the under-ice water were determined by the coulometry technique (Johnson and others, 1985). DIC measurement was calibrated with reference sea-water materials (Batch
AG; KANSO Technos Co., Ltd, Osaka, Japan) traceable to the Certified Reference Material distributed by A.G. Dickson (Scripps Institution of Oceanography, La Jolla, CA, USA). The standard deviation for DIC calculated from 20 subsamples taken from a reference sea-water material $\left(\mathrm{DIC}=2084.5 \mu \mathrm{mol} \mathrm{L}^{-1}\right.$ ) was $1.4 \mu \mathrm{mol} \mathrm{L}^{-1}$.

Chl-a concentrations were determined with a fluorometer (Model 10AU, Turner Designs, Inc., Sunnyvale, CA, USA), following the method described by Parsons and others (1984). The calibration standards $\left(0.28-282.3 \mu \mathrm{g} \mathrm{L}^{-1} \mathrm{Chl}\right.$ a) were prepared from a liquid Chl-a standard (Wako Pure Chemical Industries Ltd, Osaka, Japan) by stepwise dilution with $\mathrm{N}, \mathrm{N}$-dimethylformamide and used to calibrate the analyzer before the measurement.

Nutrient concentrations were determined with autoanalyzer systems, an AACS III (Bran+Luebbe, Tokyo, Japan) for $\mathrm{NO}_{3}+\mathrm{NO}_{2}$ and a Quaatro-Marine 5ch (SEAL Analytical, $\mathrm{Ltd}$, Fareham, UK) for $\mathrm{PO}_{4}$ and $\mathrm{SiO}_{2}$, according to the Joint Global Ocean Flux Study spectrophotometric method (JGOFS, 1996). The analyzer was calibrated with standard reference materials for nutrient analysis (Lot. AW and BG; KANSO Technos Co., Ltd.). The standard deviations of the nutrient concentrations, calculated from 20 subsamples taken from reference water samples of $10.00 \mu \mathrm{mol} \mathrm{L}^{-1}$ $\mathrm{NO}_{3}+\mathrm{NO}_{2}, 2.11 \mu \mathrm{mol} \mathrm{L}^{-1} \mathrm{PO}_{4}$ and $120.1 \mu \mathrm{mol} \mathrm{L}{ }^{-1} \mathrm{SiO}_{2}$ were $0.30,0.06$ and $1.11 \mu \mathrm{mol} \mathrm{L}^{-1}$, respectively. 